\title{
ĐÁNH GIÁ KẾT QUẢ PHẪU THUÂ̂T SỬA CHỮA TOÀN Bộ TỨ CHỨNG FALLOT Ở TRẺ EM DƯới 12 THÁNG TẠI BỆNH VIỆN ĐẠI HỌC Y DƯợC THÀNH PHỐ Hồ CHÍ MINH
}

\section{TÓM TẮT}

Mục tiêu: Nhằm đánh giá kết quả ngắn hạn sau phẫu thuật triệt để tứ chứng Fallt trẻ nhữ nhi. Phương pháp nghiên cứu: Mô tả tiến cứu. Kết quả: Kết quả đánh giá trên 19 bệnh nhân nam giới và 13 bệnh nhân nữ, các đối tượng nghiên cứu dưới 12 tháng tuổi. Đánh giá độ bão hòa oxy máu ngoai biên (SpO2) trung bình $79,72 \pm 12,28 \%$, thấp nhất là $46 \%$ và cao nhất $98 \%$. Trong đó với 13 trường hợp $(40,6 \%)$ có SpO2 <80\%. Đánh giá kết quả sau mổ ghi nhận 4 trường hợp hở van động mạch phổi nhẹ, 9 trường hợp hở trung bình và 10 trường hợp hở nặng. Các biến chứng sau mổ gồm viêm phổi ( 6 trường hợp), Suy hô hấp do hẹp khí quản/tạo hình khí quản slideplasty (1 trường hợp) và 2 trường hợp có nhiễm trùng vết mổ. Có 1 trương hợp tử vong trong bệnh cảnh suy tim, viêm phổi. Kết luân: Thực hiện phẫu thuật tiếp cận qua đường nhĩ phải và động mạch phổi với chiến lược bản tồn van động mach phổi và mở rộng vòng van tối thiểu được thực hiện một cách dễ dàng và thuâan lợi cho tất cả bệnh nhân tứ chứng Fallot. Kết quả phẫu thuật tốt, tỉ lệ bảo tồn vòng van động mạch phổi khá cao, tỉ lệ biển chứng trong giai đoạn hồi sức và theo dõi ngắn hạn sau mổ thấp và có 1 trường hợp tử vong sau mổ.

Từ khóa: Tứ chứng Fallot, bệnh tim bẩm sinh.

\section{SUMMARY}

TO EVALUATE RESULTS AFTER COMPLETE REPAIR OF TETRALOGY OF FALLOT UNDER 12 MONTHS OF AGE

Objecctives: To evaluate short-term outcomes after completed surgery for infantile tetralogy of Fallot. Methods: Prospective descriptive study. Results: Evaluation results on 19 male patients and 13 female patients, study subjects under 12 months of age. Assessment of peripheral blood oxygen saturation ( $\mathrm{SpO} 2)$ averaged $79.72 \pm 12.28 \%$, the lowest was $46 \%$ and the highest was $98 \%$. Of which, 13 cases $(40.6 \%)$ had $\mathrm{SpO} 2<80 \%$. Post-operative results, there were 4 mild regurgitation cases of pulmonary valve, 9 moderate regurgitation cases and 10 severe regurgitation cases. Post-operative complications included pneumonia (6 cases), respiratory failure due to tracheal stenosis/slideplasty ( 1 case) and 2 cases of wound infection. There were 1 case died in the hospital because of heart failure and

*Đai học Y Dược TP. Hồ Chí Minh

Chịu trách nhiệm chính: Vũ Trí Thanh

Email: thanh.vt@umc.edu.vn

Ngày nhận bài: 14/5/2021

Ngày phản biện khoa học: 2/6/2021

Ngày duyệt bài: 22/6/2021
Vũ Trí Thanh*

pneumonia. Conclusions: Performing a right atrial and pulmonary approach with the strategy of preserving the pulmonary valve and extending the minimal annulus is easily and conveniently performed in all patients with tetralogy of Fallot. The surgical results were good, the rate of preservation of the pulmonary valve annulus was quite high, the rate of complications in the recovery period and short-term follow-up after surgery was low and there was 1 case of postoperative death.

Keywords: Tetralogys of Fallot, congenital heart disease

\section{I. ĐẶT VẤN ĐỀ}

Tứ chứng Fallot (TOF) là dị tật thường gặp nhất trong nhóm bệnh tim bẩm sinh tím. Bệnh này được mô tả lân đâu tiên vào năm 1888 bởi tác giả người Pháp, Etienne Fallot [1]. Biểu hiện ban đâu của bệnh nhân TOF phụ thuộc vào mức độ tắc nghẽn đường ra thất phải (RVOT). Thông thường, bé có triệu chứng tím tái nhe khi mới sinh và tiến triển dần theo tuổi khi sự tắc nghẽn tăng lên do sự phì đại ngày càng tăng của thông mạch thất phải. Một số bệnh nhân bị tím tái đáng kể ngay sau khi sinh hoặc sau khi sinh một thời gian ngắn do hẹp hoặc tắc nghẽn nặng RVOT. Những bệnh nhân này bị tím tái thường xuyên, lượng máu đế phổi phụ thuộc vào ống động mạch hoặc các tuân hoàn bàng hệ. Dù được ghi nhận từ lâu, nhưng mãi đến năm 1945, phương pháp điêu trị phẫu thuật đâu tiên cho TOF mới được thực hiện bởi Alfred Blalock tại Đại học Johns Hopkins [2]. Ông đã tạo câu nối tạm thời giữa hệ chủ và phổi, tăng đưa máu lên phổi, cải thiện việc cung cấp oxy cho cơ thể. Năm 1954, lần đâu tiên Lillehei và Varco tại Đại học Minnesota đã sử dụng tuân hoàn ngoài cơ thể cho phẫu thuật tim đã mở ra kỷ nguyên mới cho phẫu thuật sửa chữa triệt để các bệnh lý tim mach bẩm sinh và mắc phải. Việc phấu thuât sửa chữa toàn phân bệnh tứ chứng Fallot ngày càng có những bước tiến bộ. Theo Kirklin, với những bệnh nhân TOF nếu không được điêu trị, $25 \%$ tử vong trong năm đầu đời, $40 \%$ sau 3 năm và con số này sau 10 năm là 70\% [5]. Việc chọn lựa thời điểm phẫu thuật tốt nhất vấn còn đang gây nhiêu tranh cãi, đặc biệt là phương pháp phâuu thuật và tuổi phẫu thuật. Mổ càng sớm giúp trẻ tăng trưởng và phát triển bình thường, loại bỏ tình trạng giảm oxy máu, giảm 
thiểu hoặc tránh nguy cơ suy tim và giảm rối loạn nhịp tim nhưng phải đối mặt với những khó khăn về chăm sóc trong phẫu thuật và hậu phẫu.

Bệnh thường có biểu hiện tím sớm ngay từ những tháng đầu sau sinh với diễn tiến nặng dần theo tuổi, gây ảnh hưởng rất lớn đến sự phát triển thể chất, tinh thần và hoạt động của trẻ. Nếu không được can thiệp phẫu thuật sớm, trẻ bị tứ chứng Fallot thường chết trước tuổi trưởng thành do nhiều biến chứng nặng gây nên bởi tình trạng thiếu dưỡng khí trầm trọng. Trẻ có thể bi tử vong trong các cơn thiếu oxy cấp hoặc do viêm nội tâm mạc nhiễm khuẩn, do huyết khối mạch não, áp xe não. Vì tính chất nặng nề của bệnh nên tứ chứng Fallot cần phải được chẩn đoán càng sớm và thực hiện các can thiệp ngoại khoa kịp thời, giúp trẻ có được cuộc sống bình thường [3]. Xuất phát từ điều đó, chúng tôi thực hiện nghiên cứu với mục tiêu là: Đánh giá kết quả sớm phẫu thuật sửa chữa toàn bộ tứ chứng Fallot ở trẻ em dưới 12 tháng tuổi tại bệnh viện Đại học Y Dược thành phố Hồ Chí Minh.

\section{II. ĐỐl TƯƠNGG VÀ PHƯƠNG PHÁP NGHIÊN CỨU}

2.1. Thiết kế nghiên cứu: Nghiên cứu mô tả, tiến cứu.

2.2. Thời gian nghiên cứu: Tháng $01 / 2018$ - 12/2020.

2.3. Địa điểm nghiên cứu: Khoa Phẫu thuật tim mạch, Bệnh viện Đại học Y Dược thành phố Hồ Chí Minh.

2.4. Đối tượng nghiên cứu: Tất cả bệnh nhân tứ chứng Fallot dưới dưới 12 tháng tuổi được chẩn đoán và phẫu thuật triệt để tại bệnh viện Đại học $Y$ Dược thành phố Hồ Chí Minh từ tháng $1 / 2018$ đến tháng 12/2019.

- Tiêu chuẩn lựa chọn: Bệnh nhân tứ chứng Fallot dưới 12 tháng tuổi vào thời điểm phẫu thuật. Được phẫu thuật triệt để.

- Tiêu chuẩn loại trừ Tứ chứng Fallot thể không van động mạch phổi.Tứ chứng Fallot có kèm các tổn thương tim bẩm sinh phức tạp khác: Ebtein, kênh nhĩ thất. Bệnh nhân có dị tật ngoài tim khác phối hợp có thể đe dọa tính mạng.Bệnh nhân đã có can thiệp phẫu thuật tạm thời trước đó.

2.5. Thu thập và xử lý dữ liệu: Dữ liệu được nhập liệu và phân tích bằng phần mềm Epidata 3.1 và Stata 15.0. Thống kê mô tả bằng tần số và tỉ lệ về đặc điểm đối tượng nghiên cứu và các biến số phân loại trước và sau phẫu thuật. Các biến số liên tục được biểu diễn dưới dạng trung bình \pm độ lệch chuẩn, các biến rời rạc được biểu diễn dưới dạng tần suất hoặc \%, mức ý nghĩa thống kê được tính ở mức 95\%, khoảng tin cậy cũng được tính trong khoảng $95 \%$. Biến số rời rạc được so sánh bằng thử nghiêm $\chi^{2}$. Biến số liên tục được so sánh bằng thử nghiệm T- student.

\section{KẾT QUẢ NGHIÊN CỨU}

Nghiên cứu được phân tích trên cơ sở các số liệu thu thập được từ 32 trường hợp bệnh nhân tứ chứng Fallot được phẫu thuật triệt để theo tiêu chuẩn chọn mẩu của nghiên cứu tại bệnh viện Đại học Y Dược thành phố Hồ Chí Minh. Giới tính: 19 nam giới và 13 nữ giới (tỉ lệ nam:nữ là 1,46:1). Tuổi từ 1- 12 tháng, trung bình $8,2 \pm$ 2,1 tháng tuổi, trong đó nhóm 9-10 tháng nhiều nhất với 11 trường hợp, chiếm tỉ lệ $34,4 \%$. Nhóm $\leq 6$ tháng tuổi có 9 trường hợp, chiếm tì lệ 28,1\%; nhóm trên 6 tháng tuổi có 23 trường hợp, chiếm tî lệ $71,9 \%$. Cân nặng trung bình $7,41 \pm 1,43 \mathrm{~kg}$, cân nặng thấp nhẩt là $4 \mathrm{~kg}$ và lớn nhất là $10 \mathrm{~kg}$.

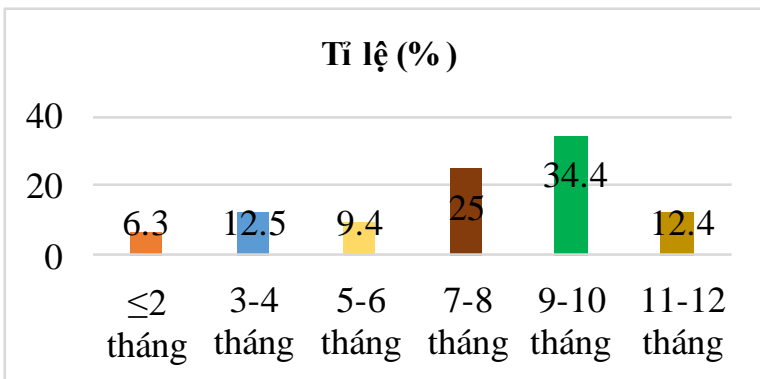

Biểu đồ 1. Phân nhóm tuổi của đôii tượng nghiên cứt

Độ bão hòa oxy máu ngoại biên (SpO2) trung bình $79,72 \pm 12,28 \%$, thấp nhất là $46 \%$ và cao nhất 98\%. Trong đó với 13 trường hợp (40,6\%) có $\mathrm{SpO} 2<80 \%$.

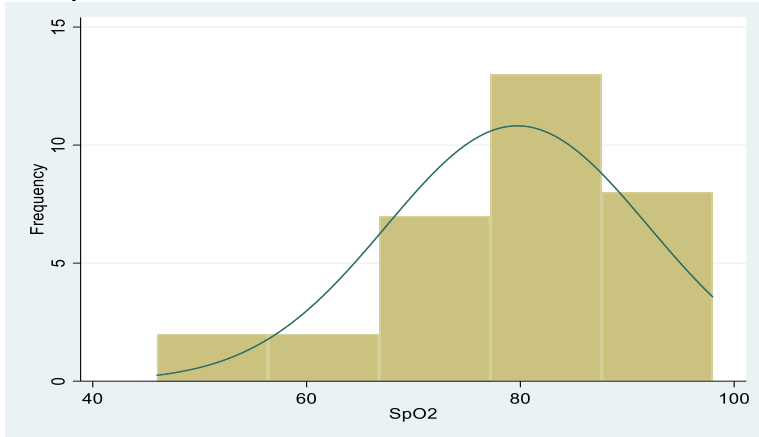

Biểu đồ 2. Độ bão hòa oxy máu ngoại biên (SpO2)

Hct trung bình $40,78 \pm 4,88 \%$, thấp nhất là $34,9 \%$ và cao nhất $55,5 \%$. Vòng van động mạch phổi ( $Z$ - Score) trung bình là $-1,18 \pm$ 1,51 với chỉ số nhỏ nhất là $-5,3$ và lớn nhất là 1,5 . Trong đó có 23 trường hợp $Z \geq-2$ (chiếm $71,9 \%$ ) và 9 trường hợp $Z<-2$ (chiếm $28,1 \%$ ). 
Kích thước vòng van ĐM phổitrung bình $8,58 \pm$ $2,32 \mathrm{~mm}$, thấp nhất là $4,4 \mathrm{~mm}$ và cao nhất là $16,8 \mathrm{~mm}$. Kích thước thông liên thất quanh màngtrung bình $10,26 \pm 1,53 \mathrm{~mm}$, thấp nhất là $5,8 \mathrm{~mm}$ và cao nhất là $13 \mathrm{~mm}$.

\begin{tabular}{|c|c|c|} 
Bảng 1. Phẫu thuật xẻ vào phễu thất phải \\
\hline $\begin{array}{c}\text { Phâuu thuật xẻ vào } \\
\text { phễu thất phải }\end{array}$ & $\begin{array}{c}\text { Tân } \\
\text { suất }\end{array}$ & $\begin{array}{c}\text { Tỉ lệ } \\
\text { (\%) }\end{array}$ \\
\hline Có & 6 & 18,8 \\
\hline Không & 26 & 81,2 \\
\hline
\end{tabular}

Bảng 2. Thời gian phẫu thuật (phút)

\begin{tabular}{|c|c|c|c|}
\hline & $\begin{array}{c}\text { Thời gian } \\
\text { (min - } \\
\text { max) }\end{array}$ & $\begin{array}{c}\text { Trung } \\
\text { vị }\end{array}$ & $\begin{array}{c}\text { Khoảng tứ } \\
\text { phân vị }\end{array}$ \\
\hline Phâ̂u thuật & $180-380$ & 252,5 & $230 ; 290$ \\
\hline Chạy máy & $75-216$ & 120,5 & 97,$5 ; 138$ \\
\hline Kẹp ĐMC & $50-140$ & 78,5 & 63,$5 ; 87,5$ \\
\hline Thở máy & $252-12240$ & 1425 & $990 ; 4140$ \\
\hline $\begin{array}{c}\text { Rút nội khí } \\
\text { quăn }\end{array}$ & $220-8640$ & 1365 & $1080 ; 2850$ \\
\hline Hồi sức & $2400-28560$ & 5580 & $3450 ; 9600$ \\
\hline
\end{tabular}

Bảng 3. Các biến chứng sau mố

\begin{tabular}{|c|c|c|}
\hline Biến chứng & Tân suất & Tỉ lệ(\%) \\
\hline Nhiêm trùng vết mố & 2 & 6,26 \\
\hline Viêm phối & 6 & 18,75 \\
\hline $\begin{array}{c}\text { Suy hô hấp do hẹp khí } \\
\text { quản/tạo hình khí quản } \\
\text { slideplasty }\end{array}$ & 1 & 3,13 \\
\hline Tử vong & 1 & 3,13 \\
\hline \multicolumn{3}{|c|}{ Bảng 4. Hơ van động mạch phổi sau mố } \\
\hline $\begin{array}{c}\text { Hở van động mạch } \\
\text { phổi }\end{array}$ & Tân suất & $\begin{array}{l}\text { Tỉ lề } \\
(\%)\end{array}$ \\
\hline Không hở & 9 & 28,13 \\
\hline Hở nhẹ & 4 & 12,50 \\
\hline Hở trung bình & 9 & 28,13 \\
\hline Hở nặng & 10 & 31,24 \\
\hline Tổng & 32 & 100,0 \\
\hline
\end{tabular}

Tỉ lệ (\%)

40

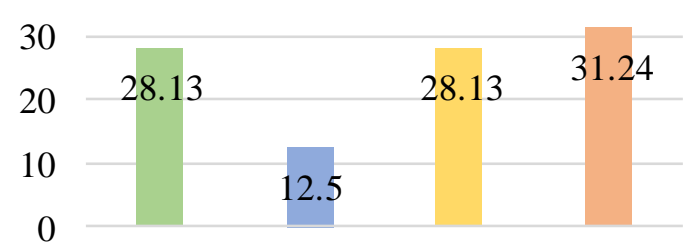

Không có Hở nhẹ Hở trung Hở nặng bình

Biểu đồ 3. Mức đô hở van đông mach phổi

Hẹp tôn lưu đường thoát thất phải (chênh áp thất P- ĐM phổi trên $50 \mathrm{mmHg}$ ): $100 \%$ các đối tượng không hẹp tồn lưu đường thoát thất phải.

Tử vong sớm sau mổ: 1 bệnh nhân tử vong chiếm $3,1 \%$

\section{BÀN LUÂN}

Trong nghiên cứu của chúng tôi, tuổi từ 1- 12 tháng, trung bình $8,2 \pm 2,1$ tháng tuổi, trong đó nhóm 9-10 tháng nhiều nhất với 11 trường hợp, chiếm tỉ lệ $34,4 \%$. Nhóm $\leq 6$ tháng tuối có 9 trường hợp, chiếm tỉ lệ 28,1\%; nhóm trên 6 tháng tuối có 23 trường hợp, chiếm tỉ lệ $71,9 \%$. Hiện nay, hầu hết các trung tâm phẫu thuật tim trền thế giới đều sửa triệt để cho bệnh nhi dưới 1 tuổi. Mổ sớm sẽ hạn chễ được nhiều biến chứng: tắc mạch não, áp xe não, cơn ngất, tử vong... đồng thời giúp trẻ phát triển thể chất và tinh thần tốt hơn.

Mặc dù bệnh Tứ chứng Fallot đã được mô tả cách đây hơn 100 năm, nhưng thật sự, việc hiểu rõ cơ chế bệnh sinh cùng sự tiến bộ của các phương pháp gây mê hồi sức chỉ phát triển vượt bậc trong vòng hai thập kỷ qua đã ảnh hưởng rất lớn đến việc tiếp cận, điều trị, kỹ thuật và thời điểm phẫu thuật. Đặc biệt, việc đánh giá chính xác mức độhẹp đường thoát thất phảisẽ quyết định chiến thuật sửa chữa một thì hay hai thì và thời điểm phẫu thuật. Trong một nghiên cứu, Seliem và cộng sự [6] đã xem xét ảnh hưởng của mức độ hẹp đường thoát thất phảivà hình thái thất phải liên quan đến tuổi của bênh nhân tại thời điểm phẫu thuật. Trong số các bệnh nhân đã được phẫu thuật trước 6 tháng tuổi, cả độ dày tuyệt đối và tỷ lệ chiều ngang của thành thất phải đều giảm đáng kể sau khi phẫu thuật. Ngược lại, những bệnh nhân được phẫu thuật sau 6 tháng tuổi cho thấy không có thay đổi đáng kể. Giải quyết sớm tình trạng phì đại và xơ hóa tâm thất phải được cho là quan trọng trong việc giảm tỷ lệ rối loạn chức năng thất phải và rối loạn nhịp thất.

Kết quả phẫu thuật Tứ chứng Fallotở trẻ sơ sinh đã được cải thiện đáng kể trong thập kỷ qua. Một nghiên cứu gộp về việc phẫu thuật Tứ chứng Fallot từ năm 1973 đến năm 1988 cho thây tỷ lệ tử vong tại bệnh viện là $18,5 \%$. Một đánh giá hồi cứu trong 26 năm cho thấy tỷ lê tử vong do phẫu thuật tạm thời ở tất cả các nhóm tuổi từ $11,1 \%$ trước năm 1990 xuống còn $2,1 \%$ sau năm 1990 [7]. Tỷ lệ tử vong trong nghiên cứu phẫu thuật triệt để tứ chúng Fallot ở trẻ sơ sinh dưới 30 ngày tuổi cho thấy tỷ lệ tử vong tại bệnh viện là $1,6 \%$. Phân tích tập trung vào nhóm tuổi trẻ nhất bị hẹp đường thoát thất phải nặng cho thấy kết quả tương đương với những 
kết quả đã công bố trước đây. Trong nghiên cứu của chúng tôi, có 1 trường hợp tử vong, chiếm tỉ lệ $3,1 \%$. Trướng hợp này bị hẹp nặng vòng van động mạch phổi, được xẻ vòng van. Sau mổ, bệnh nhân bị suy tim, viêm phổi, thở máy kéo dài và tử vong trong bệnh cảnh suy đa cơ quan.

Phẫu thuật triệt để sửa chữa toàn bộ các tổn thương của tứ chứng Fallot bao gồm mở rộng đường thoát thất phải, đóng lố thông liên thất. Mặc dù thời điểm lý tưởng cho phẫu thuật sửa chữa toàn bộ Tứ chứng Fallot vẫn là một vấn đề còn tranh cãi, các nghiên cứu trước đầy cho thấy phẫu thuật sửa chữa sớm phẫu thuật Tứ chứng Fallot ngay trong giai đoạn sơ sinh có tỉ lệ tử vong cao hơn, biến chứng nhiều hơn [4]. Phẩu thuật sửa chữa triệt để tứ chứng Fallot cho trẻ dưới 12 tháng tuổi lần đầu được thực hiện tại London, Anh. Sau đó, với sự phát triển của kỹ thuật hạ thân nhiệt sâu và ngưng tuần hoàn đã giúp cho phẫu thuật viên thuận lợi hơn rất nhiều trong lúc mổ trên những bệnh nhân nhỏ ký. Tác giả Kirklin ở Trung tâm Y khoa Alabama (Mỹ) đã mổ ở thời điểm sớm hơn và sửa chữa triệt để môt thì tứ chứ Fallot với kết quả khả quan. Từ đó, các trung tâm trên thế giới cũng thay đổi theo xu hướng này, phẫu thuật tim bẩm sinh sớm từ giai đoạn sơ sinh trong đó có sửa chữa ToF [5].

Thời điểm phẫu thuật triệt để tứ chứng Fallot hiện nay tuy chưa hoàn toàn thống nhất, nhưng nhìn chung tại nhiều trung tâm phẫu thuật tim lớn, chỉ đinh được đăt ra ở lứa tuổi 6 - 12 tháng, hoặc lớn hơn đến khoảng 18 tháng tuổi. Bên cạnh đó vẫn có nhiều trung tâm chủ trương phẫu thuật triệt để tứ chứng Fallot ở thời kì sơ sinh. Trong nghiên cứu của chúng tôi ghi nhận các đối tượng có độ tuổi từ $1-12$ tháng tuổi.

Người bệnh tứ chứng Fallot cần thiết được điều trị phẫu thuật để có được sinh lý tuần hoàn bình thường. Tuy nhiên khi chỉ định phẫu thuật triệt để được đặt ra, người ta cân nhắc những yếu tố giải phẫu không thuận lợi cho phẫu thuật triệt để. Đó là thiểu sản động mạch phổi, hẹp nặng dài đường thoát thất phải, nhiều thông liển thất, tuần hoàn bàng hệ chủ - phổi lớn. Những trường hợp bất thường động mạch vành kèm theo tiên lượng phải mở rộng vòng van động mach phổi cũng là bất lợi cho phẫu thuật triệt để một thì. Trường hợp này được chỉ định phẫu thuật tạm thời chờ đợi người bệnh đủ $10 \mathrm{~kg}$ hoặc hơn để đặt ống ghép có van từ thất phải lển động mạch phổi.

Nếu không có tuần hoàn bàng hệ đáng kể thì không có khó khăn trong việc nhận định liệu rằng các nhánh động mạch phổi có đủ kích thước cho phẫu thuật sửa chữa triệt để hay không. Ở những người bênh này, kích thước động mạch phổi trước phẫu thuật đã đáp ứng được lượng máu lên phổi để giữ độ bão hòa oxy tướng đối. Chỉ có những trường hợp nhánh động mạch phổi quá nhỏ kéo dài gây khó khăn trong việc bộc lộ và mở rộng cần cân nhắc chỉ định phẫu thuật triệt để [3].

Việc chọn lựa đường tiếp cận để sửa chữa triệt để tứ chứng Fallot có 2 đường: qua đường xẻ vào thất phải hoặc qua đường xẻ nhĩ phải và động mạch phổi. Trong nghiên cứu của chúng tôi, tất cả trường hợp đều tiếp cận qua đường xẻ nhĩ phải và động mạch phổi. Các báo cáo gần đây đều khuyển cáo nên tiếp cận qua đường mở vào xẻ nhĩ phải và động mạch phổi [3], [4], [8]. Việc kết hợp này cho phép nhìn rõ hơn các tổn thương thổng liên thất, phì đại thất phải, hẹp đường thoát thất phải, nhờ đó giải phóng hẹp đường thoátthất phải hiệu quả và tránh làm tổn thương một số cấu trúc quan trọng (van động mạch phổi, van $Đ M C$, thành trước thất phải...). Mốc cắt cơ phì đại cách vòng van ĐMC khoảng 5 $\mathrm{mm}$. Đường cắt lan dần sang trái và lên trên để gặp đường cắt qua vòng van động mạch phổi. Những bè cơ phì đại dọc bờ trái đường ra thất phải cũng cần phải cắt bỏ. Trong nhiều trường hợp, cơ thất phải phì đại rất nhiêu, cột cơ van ba lá che lấp đường ra thất phải, lúc này ngoài việc cắt cơ phì đại vùng phễu thất phải, còn phải cắt cả bè cơ phì đai thành tự do thất phải để tránh hẹp tồn lưu giữa phần buồng nhận và buồng tổng thất phải. Ở trẻ nhỏ, việc giải phóng đường ra thất phải không khó hơn ở trẻ lớn và người lớn, tuy nhiên cần những dụng cụ nhỏ hơn để cắt khoét cho hiệu quả.

Sau mổ, biến chứng hở phổi nặng kéo dài gây suy tim phải là vấn đề nan giải, do đó, các phẫu thuật viên cần tìm ra cách bảo tồn vòng van và lá van động mạch phổi, hạn chế hở phổi sau mổ. Tỉ lệ phải xẻ xuyên qua vòng van động mạch phổi để mở rộng đường thoát thất phải trong nhóm bệnh nhẩn được mổ sửa chữa trong giai đoạn sơ sinh là cao hơn, dẫn đến biến chứng hở van động mạch phổi nhiều hơn, gây suy tim phải và loạn nhịp tim [4], [8].

Trong nghiên cứu của chúng tôi, thời gian phẫu thuật từ (180-380 phút), thời gian thở máy với trung vị là 23,75 giờ $(4,2-204$ giờ), trong đó rút nội khí quản trung vị là 22,75 giờ $(3,6-144$ giờ). Những yếu tố làm tăng thời gian thở máy là: giai đoạn đầu nghiên cứu, kích thước vòng van động mạch phổi nhỏ (giá trị $Z<-2$ ), có miếng 
vá xuyên vòng van, thời gian THNCT >120 phút, và đặc biệt có biến chứng hậu phẫu.Các biến chứng sau phẫu thuật với 3 biển chứng xảy ra ở 4 bệnh nhân chiếm tỉ lệ $12,5 \%$, trong đó có 1 trường hợp bị suy hô hấp do hẹp khí quản/tạo hình khí quản slideplasty và viêm phổivới tỷ lệ $18,7 \%$ và nhiễm trùng vết mổ chiếm $6,3 \%$. Trong nghiên cứu có 1 trường hợp người bệnh tử vong do bị suy tim, viêm phổi, thở máy kéo dài và tử vong trong bệnh cảnh suy đa cơ quan, chiếm tỉ lệ 3,1\%. Tỉ lệ tử vong trong nghiên cứu của chúng tôi gần tương đương so với các nghiên cứu gộp dữ liệu đa trung tâm, tổng hợp các số liệu về phẫu thuật sửa chữa ToF trên thế giới [3], [4]. Theo các tác giả, có thể giảm thấp tỉ lê tữ vong nếu bảo vê cơ tim tốt trong lúc phẫu thuật, hạn chế tối đa những tác động xấu của quá trình chạy tuần hoàn ngoài cơ thể và hoàn thiện kỹ thuật mổ và hồi sức sau mổ.

\section{KẾT LUÂN}

Tứ chứng Fallot là bệnh lý tim bẩm sinh nặng với các triệu chứng bao gồm khó thở và những cơn tím xảy ra đột ngột, có thể gây tử vong. Phẫu thuật sửa chữa toàn bộ tứ chứng Fallot cho trẻ dưới 12 tháng tuổi tiếp cận qua đường nhĩ phải và động mạch phổi với chiến lược bảo tồn van động mạch phổi với tỉ lệ tử vong thấp và ít biến chứng trong giai đoạn hồi sức và theo dõi ngắn hạn sau mổ đã khẳng định tính an toàn, hiệu quả của phẫu thuật.

\section{TÀI LIÊU THAM KHẢO}

1.Bacha E.A, Scheule A.M, Zurakowski D, Erickson L.S, Hung J, Lang P et al (2001). Long-term results after early primary repair of tetralogy of Fallot. J Thorac Cardiovasc Surg, 122; 154-161.

2.Blalock A, Taussig HB (1945). The surgical treatment of malformation of theheart in which thereis pulmonary stenosis or pulmonary atresia.JAMA; 128:189.

3. Bobae Jeon MD, Dong-Hee Kim MD et al (2020). Surgical treatment of tetralogy of Fallot in symptomatic neonates and young infants. The Journal of Thoracic and Cardiovascular Surgery, Volume 159, Issue 4, April, Pages 1477-1478

4. Loomba R. S., Buelow M. W., Woods R. K. (2017). Complete Repair of Tetralogy of Fallot in the Neonatal Versus Non-neonatal Period: A Metaanalysis. Pediatr Cardiol,38, (5), pp. 893-901

5. Kirklin JW, DuShane JW, Patrick RI, et al (1955): Intracardiac surgery withthe aid of a mechanical pump-oxygenator system (Gibbon type): reportof eight cases. Mayo Clin Proc; 30:201.

6. Seliem MA, Wu YT, Glenwright K. (1995). Relation between age at surgeryand regression of right ventricular hypertrophy in tetralogy of Fallot. Pediatr Cardiol; 16(2):53-55. Vol. 232

7. Knott-Craig CJ, Elkins RC, Lane MM, et al (1998). A 26-year experiencewith surgical management of tetralogy of Fallot: risk analysis formortality or late reintervention. Ann Thorac Surg; 66:506-511

8. Van Der Ven J. P. G., van den Bosch E., Bogers Ajcc, Helbing W. A. (2019). Current outcomes and treatment of tetralogy of Fallot. F1000Res,doi: 10.12688/ f1000research. 17174.1. eCollection 2019

\title{
TÍNH ĐA HÌNH TRÌNH TỰ GEN MÃ HÓA ND5 VÀ ND6 Ở' NGƯờI DÂN TộC GIARAI VÀ ÊĐÊ SỐNG Ở TÂY NGUYÊN
}

\author{
Nguyễn Minh Tùng*, Nguyễn Văn Ba**, Nguyễn Đăng Tôn***
}

\section{TÓM TẮT}

Mục tiêu: Xác định tính đa hình trình tự gen mã hóa ND5 và ND6 ở người dân tộc GiaRai và Ede sống ở Tây Nguyên. Đối tượng và phương pháp nghiên cứu: 54 mâ̂u máu ngoại vi của người bình thường khỏe manh, thuộc các dân tộc Giarai và Ede được tách chiết DNA, khuếch đại gen ND5, ND6 bằng phương pháp PCR, tinh sạch DNA, giải trình tự tự động. Sau

\section{*Hoc viện Quân Y \\ **Bênh viện Quân Y 103 \\ ***Viện nghiên cúu hệ gen}

Chịu trách nhiệm chính: Nguyễn Minh Tùng

Email: bsqytung@gmail.com

Ngày nhận bài: 5/5/2021

Ngày phản biên khoa học: 26/5/2021

Ngày duyệt bài: 18/6/2021 đó, trình tự gen ND5 và ND6 được phân tích và so sánh với trình tự chuẩn bằng phần mềm chuyên dụng, so sánh tính đa hình ND5, ND6 với tính đa hình được công bố trên MITOMAP. Kết quả: Đã xác định được trình tự gen mã hóa ND5, ND6 và xác định được tính đa hình trình tự gen mã hóa ND5 và ND6 ở người dân tộc GiaRai và Ede sống ở Tây Nguyên. Kết luận: Nighiên cứu đã cung cấp số liệu về tính đa hình trình tự gen mã hóa ND5 và ND6 ở người dân tộc GiaRai và Édesống ở Tây Nguyên.

Tư khóa: Tính đa hình, ND5, ND6, Gia Rai, Ede, Tây Nguyên.
SUMMARY
MITOCHONDRIAL NADH DEHYDROGENASE SUBUNIT 5 AND SUBUNIT 6 GENE POLYMORPHISMS IN GIARAI AND EDEETHNIC PEOPLE LIVING IN THE CENTRAL HIGHLANDS 